\title{
Racial Residential Segregation by State Court Enforcement of Restrictive Agree- ments, Covenants or Conditions in Deeds is Unconstitutional
}

\author{
D. O. McGovney*
}

\begin{abstract}
A AGREEMENT between owners of several residential properties that none of them, their heirs, executors, administrators or assigns should sell or transfer any interest therein to any Negro, and that when recorded the agreement should continue in force for ninetynine years, was recently held by the Supreme Court of Oklahonia to be enforceable. ${ }^{1}$ Fifteen years after the agreement was recorded two of the owners sold some of the lots to a Negro. At the suit of an owner of some of the other lots the trial court held the restrictive agreement enforceable and gave a judgment cancelling the deeds to the Negro. The state supreme court in sustaiming this judgment made no comment on the fact that the breach came in the fifteenth, instead of the ninety-ninth year. Nor did it say whether the owner who sued or those who sold were original parties to the agreement, or were heirs or assigns of those parties. Moreover, the court in effect awarded punitive damages against the Negro by giving the plaintiff a judgment for costs and attorneys' fees, making the judgment a lien on the lots, a lien prior to that given the Negro for the purchase price. Thus the Negro was deprived of the property he had bought from a willing seller and mulcted for buying it. The court did not say that the Negro had actual knowledge of the restrictive agreement nor that his vendor had. It assumed that recordation gave constructive notice to all persons who might buy or sell during the life of the agreement.

In its infliction of punitive damages the case is umque but otherwise it is typical of the decisions herein to be discussed. The question

*A.B., Indiana University, 1901 ; M.A., Harvard University, 1904 ; LL.B., Columbia University, 1907. Professor of Law, University of California. Author of CASES on CoNStTturional Law (2d ed. 1934), Materials For the Study of AdnTnistrattve Law (1940), and of articles in various legal periodicals. The author acknowledges the able assistance of Mr. Irving G. Tragen of the Board of Editors in the search for authorities and preparation of notes.
\end{abstract}

\footnotetext{
1 Lyons v. Wallen (1942) 191 OkJa. 567, 133 P. (2d) 555.
} 
to which this discussion will be addressed is, where a state court gives a judgment enforcing such a racial discrimination with respect to the ownership or use of residential property, is its action state action in violation of the Equal Protection Clause of the Fourteenth Amendment: "nor shall any State ... deny to any person within its jurisdiction the equal protection of the laws"?

This constitutional question was not raised by the pleadings in the Oklahoma case. Gratuitously the court mentions it and disposes of it in a single sentence:

"Such contracts are not prohibited by the Fifth, Thirteenth or Fourteenth Amendments to the federal constitution. Corrigan v. Buckley, 271 U.S. 323."2

The fact that the court as an organ of the state was taking action to enforce the contract was not commented on.

Another Supreme Court, of very different rank, that of Westchester County, New York, disposed of the constitutional question with the same brusqueness, saying nothing more than:

"It is sufficient to say that the United States Supreme Court has held that a covenant of this precise character violated no constitututional right. Corrigan v. Buckley, 271 U.S. 323."3

The highest court of Kentucky, of Maryland ${ }^{5}$ and of Wisconsin," and an intermediate appellate court in Missour $\mathrm{i}^{\mathrm{r}}$ have also cited Corrigan v. Buckley as settling all the constitutional issues involved.

The most cursory examination of the Supreme Court's decision in Corrigan v. Buckley would disclose that it could not and did not settle anything about the application of the Fourteenth Amendment to the states, for the case came to the Supreine Court on appeal from a court in the District of Columbia and involved solely a question of the law of the District, to which the Fourteenth Amendment has no application. The Supreme Court dismissed the appeal for want of jurisdiction. What constitutional issue, if any, it decided, I slall later

2 Ibid. at 569,133 P. (2d) at 558.

3 Ridgway v. Cockburn (1937) 163 Misc. 511, 514, 296 N.Y.S. 936, 942.

4 United Cooperative Realty Co. v. Hawkins (1937) 269 Ky. 563, 565, 108 S.W. (2d) 507, 503 .

5 Meade v. Dennistone (1938) 173 Md. 295, 302, 296 Atl. 330, 333.

6 Doherty v. Rice (1942) 240 Wis. 389, 397, 3 N.W. (2d) 734, 737.

7 Thombill v. Herdt (Mo. App. 1939) 130 S.W. (2d) 175, 178. 
discuss. ${ }^{8}$ It is sufficient here to emphasize that the question was not before it, whether state court enforcement of the kind of agreements here in question is a violation of the Equal Protection Clause of the Fourteenth Amendment.

The question has never been presented to the Supreme Court.

The nearest to a decision of the question by any federal court is in Gandolfo v. Hartman, ${ }^{9}$ in 1892 , by the Circuit Court of the United States, S.D., California. The court refused to enforce a covenant in a deed that the grantee should never rent the property "to a Chinaman". District Judge Ross was clear in his opinion that enforcement of such a racial discrimination by the courts of California would be state denial of equal protection of the laws. He assumed that a federal court sitting in a state was subject to the same restriction. If Judge Ross was right on the latter point, as he seems to have been, the case is squarely in point. Recently a superior court judge in California referred to this decision as a "stray" case. ${ }^{10}$ Certainly the Supreme Court has never excluded it fronl the fold.

A few state courts have given the constitutional question fuller consideration than the state cases above cited but all superficially and inadequately. Before coming to them, let us see how far this novel doctrine of the legality of such restraints on alienation has spread. The relatively few state courts that have passed on the legality of such restraints have had to determine whether under the land law of the state, apart from constitutionality, such a restraint on alienation is void. Unquestionably at common law until very recent times a restraint on alienation that closed "the market afforded by a whole race of the human family"11 was void as against public policy. True it is that the common law's notion of public policy was concern for the interest of an owner, protecting the vendability of the property rather than interest in the welfare of persons whom the restraint, if legal, cut off from buying it. Protection of sellers rather than prevention of discrimination against potential buyers was the theme. It is true also that some very limited restraints on alienation were recognized as valid, but the older authorities show conclusively that

\footnotetext{
8 Infra p. 34.

9 (1892) 49 Fed. 181.

10 Los Angeles Daily Journal, October 7, 1944, at 4.

11 Quoted from White v. White (1929) 108 W. Va. 128, 140, 150 S.E. 531, 539.
} 
a restraint barring sale to all of a race or to all of all races except Caucasions would not have been tolerated..$^{12}$

The first case holding that a restraint against sale to any Negro was legal and enforceable under the land law of the state came in 1915, decided by the Supreme Court of Louisiana. ${ }^{13}$.I shall not atteinpt to inquire to what extent that decision was a departure from the Civil Law of Louisiana as previously interpreted or how closely the civil law rule against restraints on alienation parallels that of the common law.

The first decision in a common law jurisdiction holding a restramt against sale to any Negro legal was by the Supreme Court of Missouri in $1918 .^{14}$

The next court to consider the question was the Supreme Court of California, in 1919. ${ }^{15}$ There were two covenants or conditions in a deed, (1) "that the said property shall not be sold, leased or rented to any persons other than of the Caucasian race" and (2) "nor shall any person or persons other than of Caucasion race be permitted to occupy such lot or lots."

The court held the first covenant or condition void as forbidden by California's codified version of the common law rule against restraints on alienation. ${ }^{16}$ The court, however, distinguished the second covenant or condition, saying, "It is not a restraint upon the alienation, but upon the use of the property." The buyer was a Negro and the court held that he should be enjoined from occupying the property although it held that he had legally acquired title to it.

The court's distinction between the two covenants is unsound. Speaking both technically ${ }^{17}$ and from a practical point of view both covenants were restraints on alienation, and on common law prin-

12 See John Chipman Grax, Restratnts on Altenation (1882) (an exhaustive digest of the cases citing none that involved a wholesale restraint such as we are discussing).

13 Queensborough Land Co. v. Cazeaux (1914) 136 La. 724, 67 So. 641, L.R.A. 1916B 1201, Ann. Cas. 1916D 1248.

14 Koehler v. Rowland (1918) 275 Mo. 573, 205 S.W. 217, 9 A.I.R. 107.

15 Los Angeles Investment Co. v. Gary (1919) 181 Cal. 680, 186 Pac. 596, 9 A.L.R. 115.

16 CAL. Crv. CODE \$711: "Conditions restraining alienation, when repugnant to the interest created, are void."

17. The court seems to have tliought that by declaring the covenant against occupancy not to be a restraint on alienation at all it relieved itself of the necessity of determing whether as a restraint it was so substantial as to be an illegal restraint. It seems 
ciples both should have been held to be illegal restraints. The covenant against sale or lease to any non-Caucasion was held an illegal restraint because it restricted the seller's market to Caucasion buyers, excluding all non-Caucasions. The restriction against occupancy as applied to residential property has substantially the same effect for the principal market for residential property is among persons who may lawfully reside in it. The latter cuts off substantially all of the same buyers as the former. The difference is too small to say that one is a substantial restraint and the other is not. That the restriction against occupancy by an unwanted class increases the market price of other property in the neighborhood, as it often does but sometimes does not, is beside the point for the owner of this property had his market restricted. His profitable use of the property while retaining title was also restricted. Although he might legally lease to a nonCaucasian, the covenant against leasing being void, non-Caucasians ordinarily do not want to take a lease of residential property subject to a restriction that they cannot live in it. All that can be said is that a restriction against use of the property as a residence by a nonCaucasian is a restraint on alienation but little less in degree than a restriction against sale or lease to a non-Caucasian. Later it will appear that on the constitutional issue there is no difference between these two degrees of restraint.

The courts that hold race restrictions of either kind enforceable make no distinctions as to the method by which they are created, whether by covenants or conditions in deeds or by agreements be-

not to have doubted that technically the covenant was not a restraint on alienation, assuming that notwithstanding the covenant a full fee simple could be conveyed to a non-Caucasian. There is a fallacy in that assumption, although it appears to be accepted in TIffany, The Law of ReaI Property (1939) \$1345, n. 21, where the author concedes, however, that as a "practical matter" the covenant is a restraint on alienation. The fallacy from a purely technical point of view is that the covenant does prevent the seller from conveying a full fee simple. A fee simple is a bundle of legal relations with respect to land. One of the sticks in the bundle, one of the incidents of ownership, is the privilege of residing on the land. Analytical jurists tell us that "alienation" involves destruction of the riglits of the grantor and creating similar riglits in the grantee. If one of the rights of the grantor camiot be re-created in the grantee the grantor's power of alienation is curtailed. There is a restraint on alienation. Once it is recognized to be such, the next question is whether in its effect it is a substantial restraint and therefore illegal at common law. Compare Stares, LAw of Future Interests (1936) \$460, where the discussion confuses these two questions. A restriction against use of residential property as a residence differs from a restriction against other uses such as that no intoxicants shall be sold on the property. While the latter is a restraint upon alienation it does not diminish the vendability of the property sufficiently to be held an illegal restraint. 
tween several owners independent of any instruments of conveyance. Since the decision of the Supreme Court in 1917 in Buchanan $v$. Warley ${ }^{18}$ that racial residential segregation, or racial zoning, by statute or city ordinance is unconstitutional, the attempt to approximate the result by neighborhood agreements seems to have become more prevalent.

We may now briefly show the line-up of the relatively few courts that have passed upon racial restrictions of either kind.

(1) Holding that a restriction against sale or lease to any member of a specified race or races is a legal restraint: the supreme courts of Alabama, ${ }^{10}$ Colorado, ${ }^{20}$ Kansas, $^{21}$ Louisiana, ${ }^{22}$ Missouri, ${ }^{23}$ Oklaho$\mathrm{ma}^{24}$ and the United States Court of Appeals for the District of Columbia, ${ }^{25}$ although the Supreme Court of the United States, which has the last word on the judge-made law of the District, has not yet spoken.

Holding such restrictions against sale or lease illegal are the supreme courts of California, ${ }^{26}$ Michigan $^{27}$ and West Virginia, ${ }^{28}$ and an

18 (1916) 245 U.S. 60.

19 Wyatt v. Adair (1926) 215 Ala. 365, 110 So. 801. The case of Moseby v. Roche (1936) 233 Ala. 280, 171 So. 351, is different, enforcing against a Negro covenantor his agreement not to allow his beach property to be used for any commercial purpose, including using it as a bathing beach or picnic ground for Negroes. Enforcement of that restriction against the covenantor seems not unconstitutional.

20 Chandler v. Ziegler (1930) 88 Colo. 5, 291 Pac. 822; Stewart v. Cronan (1940) 105 Colo. 392; 98 P. (2d) 999.

21 See Clark v. Vaughan (1930) 131 Kan. 438, 292 Pac. 783, holding the restriction in suit not enforceable because of change of conditions.

22 Queensborough Land Co. v. Cazeaux, supra note 13.

${ }^{23}$ Koehler v. Rowland, supra note 14; Porter v. Johnson (1938) 232 Mo. App. 1150, 115 S.W. (2d) 529; Thombill v. Herdt, supra note 7; Porter v. Pryor (Mo. 1942) 164 S.W. (2d) 353.

24 Lyons v. Wallen, supra note 1.

25 Corrigan v. Buckley (1924) 299 Fed. 899, appeal disnr. (1926) 271 U.S. 323 ; Torrey v. Wolfes (1925) 6 F. (2d) 702 ; Castleman v. Avignone (1926) 12 F. (2d) 326; Russell v. Wallace (1929) 30 F. (2d) 981, cert. den. (1929) 279 U.S. 871; Cornish v. O'Donohue (1929) 30 F. (2d) 983, cert. den. (1929) 279 U.S. 871; Edwards v. West Woodbridge Theatre Co. (1931) 55 F. (2d) 524; Grady v. Garland (1937) 89 F. (2d) 817, cert. der. (1937) 302 U.S. 694; Mays v. Burgess (Jan. 29, 1945) U.S. Court of Appeals, D.C. No. 8831; Hundley v. Gorewitz (1942) 132 F. (2d) 23 (refusing to enforce the restriction in suit because of change of conditions).

26 Los Angeles Investment Co. v. Gary, supra note 15; Janss Investment Co. v. Walden (1925) 196 Cal. 753, 239 Pac. 34; Title Guarantec \& Trust Co. v. Garrott (1919) 42 Cal. App. 152, 183 Pac. 470; Stratton v. Cornehus (1929) 99 Cal. App. 8, 277 Pac. 
inferior court in Ohio, ${ }^{29}$ the only decision so far in that state. Thus the line-up is six states to four.

(2) Holding that a restriction against use or occupancy by any member of a specified race or races is a legal restraint: the supreme courts of California, ${ }^{30}$ Maryland, ${ }^{31}$ Michigan, ${ }^{32}$ Wisconsin, ${ }^{33}$ and an inferior court in New York. ${ }^{34}$ So far as a dictum commits a court, West Virginia may be added to this group..$^{35}$ No doubt also the six state courts that sustain restraints against sale or lease would also join this group if occasion presented itself. North Carolina has joined at least one group, perhaps both. ${ }^{36}$

All told the courts of twelve states, counting an inferior court in New York, have held restraints of the one kind or the other judicially enforceable. In several of these decisions the constitutional question has not been mentioned. The courts in thirty-five ${ }^{37}$ states have not yet spoken.

893 (a covenant against leasing property does not prevent selling that property) ; Foster v. Stewart (1933) 134 Cal. App. 482, 25 P. (2d) 497.

27 Porter v. Barrett (1925) 233 Mich. 373, 266 N.W. 532, 42 A.L.R. 1267.

28 White v. White (1929) 108 W. Va. 128, 150 S.E. 531, 66 A.L.R. 529.

29 Williams v. Commercial Land Co. (1931) 34 Ohio Law Rep. 559.

30 Los Angeles Investment Co. v. Gary, supra note 15; Wayt v. Patee (1928) 205 Cal. 46, 269 Pac. 660; Fairchild v. Rames (1944) 24 Adv. Cal. 812, 151 P. (2d) 260 (a covenant restraining use or occupancy is vahi; however, it will be declared invahid if neighborhood conditions have so changed that enforceinent could not achieve the original purpose of the covenant); Forest Lawn Ass'n v. de Jarnette (1926) 79 Cal. App. 601, 250 Pac. 581; Littlejohns v. Henderson (1931) 111 Cal. App. 115, 295 Pac. 95; Letteau v. Ellis (1932) 122 Cal. App. 584, 10 P. (2d) 496 (although declaring a covenant against use by non-Caucasians valid, the court refused to apply it in this case as neighborhood conditions had changed); Burkhardt v. Lofton (1943) 63 Cal. App. (2d) 230, 146 P. (2d) 720; and Stone v. Jones (1944) 66 Adv. Cal. App. 313, 152 P. (2d) 19.

31 Meade v. Dennistone (1938) 173 Md. 302, 196 Atl. 330.

32 Parmalee v. Morris (1922) 218 Mich. 625, 188 N.W. 330, 38 A.L.R. 1181; Shulte v. Starks (1927) 238 Mich. 102, 213 N.W. 102.

33 Doherty v. Rice (1942) 240 Wis. 389,3 N.W. (2d) 734.

34 Ridgway v. Cockburn (1937) 163 Misc. 511, 296 N.Y.S. 936.

35 White v. White, supra note 28.

30 Where the defendant, an owner of a tract of land which he proposed to subdivide into residential lots, sold some of the lots to the plaintiff and contracted with him that all the remaining lots, when sold, would be conveyed by deeds containing restrictions against sale to or occupancy by any Negro, the plaintiff was held entitled to maintain an action for damages upon the defendant's subsequently conveying some of the lots to a State School for the Blind and Deaf by deeds not containing either of the promised restrictions. Eason v. Buffaloe (1930) 198 N.C. 520 , 152 S.E. 496.

37 While Ohio, the thirteenth, has spoken through an inferior court her record is clear that a restriction against sale or lease is illegal, without any suggestion of an opinion on the restraint against use. Williams v. Commercial Land Co., supra note 29. 
In some of the jurisdictions that have enforced racial residence restrictions of the one kind or the other, enforcement has been refused in specific instances on so-called equitable grounds. ${ }^{38}$ Because of infiltration of members of the unwanted race into the restricted area or into areas closely adjacent to it a judicial discretion has been exercised to relieve the parties to the agreement of a bad bargain, where enforcement would curtail the inarket for the restricted property without protecting the benefited property from a shrinkage in value that has already occurred. The discriminatory covenantors are relieved from a white elephant.

Thus the Supreme Court of Kansas sustained a trial court's refusal to enforce a neighborhood agreement against sale, lease or sublease to any person or persons "commonly called negroes" on the ground that by reason of change in the neighborhood a sale to a Negro would cause "very little, if any" depreciation in the market value of the properties intended to be benefited. The court said the case did not involve "race prejudice or feeling" but the "cold business proposition" of lack of white demand for any of the properties, real estate dealers having testified that they could interest no white person in buying. ${ }^{39}$

In determining whether to relieve the covenantors of their bargain there is some diversity among the courts as to the weight to be given changes in areas surrounding the restricted area as distinguished from changes within the restricted area itself. Thus where the owners of eight adjoining lots, six facing one street and two at their rear facing another street, had entered into mutual agreements against sale to any Negro, the owners of the six brought a bill to have the agreement cancelled as a cloud on their titles, meaning, of course, a bar to profitable use or disposal of the properties. The two other owners opposed. The United States Court of Appeals for the District of Columbia in holding that the relief sought should be denied said, "The object of the restriction here was to prevent the imvasion of the restricted property by colored people, not the invasion

38 Fairchild v. Raines, supra note 30; Letteau v. Ellis, supra note 30; Clark v. Vaughn (1930) 131 Kan. 438, 292 Pac. 783; Meade v. Dennistone (1938) 173 MAd. 295, 196 Atl. 330, 114 A.L.R. 1227; Pickel v. McCawley (1931) 329 Mo. 166, 44 S.W. (2d) 857; Thornwall v. Herdt, supra note 7; Grady v. Garland (1937) 89 F. (2d) 817, cert. den. (1937) 302 U.S. 694; Hundley v. Gorewitz (1942) 132 F. (2d) 23.

39 Clark v. Vaughan, supra note 38. 
of property surrounding it." ${ }^{40}$ It seems, however, that the majority ${ }^{41}$ of the court had an eye to the white residential district to the eastward beyond these eight lots, saying that this little block "furnishes a conplete barrier agaimst the eastward movement of colored population into the restricted area-a dividing line." The niajority may not have intended to say that no changes outside of but near the restricted area should influence decision for they said that the crucial question was whether there had been changes in the environment that made the restricted area "unfit or unprofitable for use by enforcement of the restriction," that is, "unfit or unprofitable" if use was limited to whites.

A Missouri court has said that "changes in the territory surrounding the covenanted area will not of itself [sic] be sufficient to destroy the restrictions. ... The fact that changed conditions render the restriction less valuable will not prevent their [sic] enforcement if the restrictions remain of substantial value. . . . Nor will courts refuse to enforce restrictions even if the property be of more monetary value with restrictions removed. There are soine rights nore valuable than money." ${ }^{2 z}$ For this court, the "cold business proposition" is modified where one of the covenantors insists upon the letter of the bond that he be saved from living close to a Negro family. Not concern for the welfare of Negroes or other racial minorities but the prejudiced predilections of a covenantor modify the "cold business proposition".

That the welfare of the excluded race, in that case Negroes, is an iniportant factor to be considered has for the first time been stated by Justice Traynor of the Supreme Court of California in a concurring opinion in a recent case. ${ }^{43}$

The trial court had enjoined the Negro defendants from residing on one of sixty-nine lots in the City of Los Angeles all of which were bound by restrictive agreements against use by non-Caucasians, although the Negroes had legally bought the property, under the California doctrine.14

The California Supreme Court took the view that it would be inequitable to enforce the agreement if changes in the surrounding neighborhood made it no longer beneficial to the parties, and re-

40 Grady v. Garland (1937) 89 F. (2d) $817,819$.

11 Associate Justice Stephens dissented.

42 Porter v. Johnson (1938) 232 Mo. App. 1150, 1158, 115 P. (2d) 529, 534.

43 Fairchild v. Raines, supre note 30.

14. Supra p. 8. 


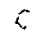

manded the case to the trial court for more definite findings on this point. Justice Traynor concurred but urged that the trial court should also consider "whether enforcement would be contrary to the public interest in the use of land in urban communities where people are concentrated in limited areas." 45 The problem of what restraints on alienation are lawful as a matter of land law, apart from constitutionality, has in the past been determined by judges from the standpoint of a public policy in favor of a free market for land, a freedom to vend to the greatest advantage to the owner. Justice Traynor invoked a broader view of public policy,--that public policy and public welfare is involved in enforcement of private contracts that prevent minority groups from obtaining decent housing. Justice Traynor said:

"... the influx of negroes into urban communities in response to the increasing demands of industry for labor, together with race segregation ... have made it impossible for many negroes to find decent housing in large centers of population. ... .

"In the present case a residential district populated by colored people now surrounds the restricted area on three sides. The question whether the restricted area shall stand as a barrier against expansion of the negro district cannot be determined entirely by findings with regard to property values and the interests of property owners. It is also necessary to determine whether maintenance of this barrier would deprive the colored population of any feasible access to additional housing and compress it within the inflexible boundaries of its present district at the risk of a congestion whose evils would inevitably burst the bounds of that district.

"The trial court should therefore be directed to make findings as to the housing facilities available in the district occupied by the colored population and to determine whether there is a need for additional housing that would justify an expansion of the district by absorption of the restricted area." 46

This broader public policy has been refused consideration by a Missouri appellate court in a case arising out of restrictive agreements in Kansas City, Missouri. In spite of evidence that only eighteen new residences for Negro occupancy had been built in the city during the past fifteen years and that the restricted area blocked the natural expansion of the Negro area that surrounded it on three sides, the court rejected as of no weight the argument that enforcement of

\footnotetext{
15 Supra note 30 at 824,151 P. (2d) at 627.

$46 \mathrm{Ibid}$. at $826,828,151$ P. (2d) at $628,629$.
} 
such restrictions worked a hardship on 50,000 Negro residents who had difficulty in finding homes. ${ }^{4 \pi}$

The problem of racial residence restrictions is not peculiar to Negroes, although constituting nearly a tenth of our citizenry they are the largest group affected. In the Pacific Coast states discriminatory restrictions usually proscribe all non-Caucasions, both citizens and aliens. In the Southwest it is common specifically to proscribe Mexicans and American citizens of Mexican descent, e.g. "persons commonly called Mexicans." ${ }^{48}$ A residential subdivision adjacent to Fresno, California, is covered by restrictive agreements "that neither said premises, nor any part thereof, shall be used in any manner whatever or occupied by any Negro, Chinese, Japanese, Hindu, Armenian, Asiatic, or native of the Turkish Empire, or descendant of above naned persons, provided however, that such a person may be employed by a resident upon said property as a servant for such resident." Armenians and nearly all natives of the Turkish Empire are whites, or members of the Caucasian race. From a constitutional standpoint there seems to be no distinction between state enforcement of prejudice against all Negroes or all Chinese and state enforcement of prejudice against some subdivision of the white race, such as all Armenians or all Jews.

\section{THE CONSTITUTIONAL QUESTION}

The question whether state court enforcement of restrictive residence agreements discriminating against particular races is a violation of the Equal Protection Clause of the Fourteenth Amendment has been raised by pleading in very few cases, so far as the printed reports disclose. ${ }^{49}$ It has commonly been discussed by the courts on their own motion, and quite properly so, in deciding whether such restraints on alienation are contrary to public policy. This approach seems to cause judges to think that the issue is whether such agreements between private persons are illegal or unconstitutional in and

47 Porter v. Johnson (1938) K. C. Court of Appeals, 115 S.W. (2d) 529.

48 I PaUd S. Taxtor, Mexican Labor In the United States (1928-1933) 80, 208; 2 ibid. 226; Paut S. Taylor, An American Mexacan Frontier (1934) 226. See the factual situation presented in Miller v. Jersey Coast Resorts Corp. (1925) 98 N. J. Eq. 289, 130 Atl. 824.

49 It was properly pleaded in Ridgway v. Cockhurn, supra note 3, if the court's opinion is correct in stating that the defendant pleaded "that the enforcement of the covenant ... would deny her the equal protection of the laws, in violation of the ... Fourteenth Amendment." Italics added. 
of themselves, obscuring the real issue,-whether state court enforcement of them is forbidden by the Equal Protection Clause. The state court opimions that go beyond citing Corrigan v. Buckley as completely decisive have invariably said that the issue has been settled by the interpretation given by the Supreme Court of the United States to the Equal Protection Clause in deciding the Civil Rights Cases.

Thus the Supreme Court of California has said nothing more on the constitutional issue than:

"Construing this amendment, the Supreme Court of the United States has held in a number of instances that the inhibition applies exclusively to action by the state, and has no reference to action by individuals, such as is involved here. United States v. Craikshank, 92 U.S. 542; Virginia v. Rines, 100 U.S. 313; United States v. Harris, 106 U.S. 629; Civil Rights Cases, 109 U.S. 3." 50

The California court saw only the "action by individuals", not perceiving the real issue,--state aid and enforcement by decrees of its courts.

A few other state courts have disposed of the issue in exactly the same manner. ${ }^{51}$

The Supreme Court of Louisiana, confining its notion of state action to action by the state's legislature, said:

"The fourteenth amendment, in so far as prohibiting discrimination against the negro race, applies only to state legislation, not to the contracts of individuals. Civil Rights Cases, 109 U.S. 3." ${ }^{62}$

No doubt these courts were relying upon the same passages in Supreme Court opinions that later were quoted in the dictum of $\mathrm{Mr}$. Justice Sanford in Corrigan v. Buckley, stating:

"And the prohibitions of the Fourteenth Amendment "have reference to state action exclusively, and not to any action of private individuals'. Virginia v. Rives, 100 U.S. 313, 318; United States $v$. Harris, 106 U.S. 629, 639. 'It is state action of a particular character

50 Los Angeles Investment Co. v. Gary, supra note 15, at 683, 186 Pac. at 598.

${ }^{61}$ Chandler v. Ziegler (1930) 88 Colo. 5, 6, 291 Pac. 822, 823; Meade v. Dennistone (1938) 173 Md. 295, 302, 196 Atl. 330, 333; Parmalee v. Morris (1922) 218 Mich. 625, 627, 188 N.W. 330; Porter v. Barrett (1925) 233 Mich. 373, 376, 206 N.W. 532, 533.

52 Queensborough Land Co. v. Cazeaux, supra note 13 at 726, 678 So. at 693. 
that is prohibited. Individual invasion of individual rights is not the subject of the Amendment.' Civil Rights Cases, 109 U.S. 3, 11."53

Far from sustaining state enforcement of the racial discrimimation made by these restrictive agreements the passages quoted command an opposite conclusion. So far as such agreements operate without state aid they are indeed purely the acts of individuals. But when the discriminatory objectives of private persons cannot be attained without calling upon the state for aid, sanction or enforcement, and that aid is given, unconstitutional action by the state has been taken. In the opinion of the Court in the Civil Rights Cases the sentence next following the one above quoted is:

"It [the Fourteenth Amendment] nullifies and makes void all State legislation, and state action of every kind . . . which denies . . . the equal protection of the laws." 54

That the prohibitions of the Amendment that "no State shall ...." "relate to and cover all the instrumentalities by which the state acts" 55 has ever since been the holding of the Court, whether the state instrumentality acting was a legislative, executive, judicial or administrative organ of the state. ". . whoever by virtue of public position under a state government deprives another of any right protected by that amendment against deprivation by the state violates the constitutional inhibition; and as he acts in the name of the state and for the state, and is clothed with the state's powers, his act is that of the state." 56

Even where the specific action taken by state officials is unauthorized by, or contrary to, state law their action has been imputed to the state, applying the principle of respondeat superior, the state having put them in official position to take some action in the premises. ${ }^{57}$ Doubts have been expressed on some applications of this doctrine. ${ }^{58}$

53 Supra note 25,271 U.S. at 330.

64 (1883) 109 U.S. 3, 11. Italics added.

65 Raymond v. Clicago Traction Co. (1907) 207 U.S. $20,36$.

56 Ibid. So also Home Tel. \& Tel. Co. v. Los Angeles (1913) 227 U.S. 278, and the cases therein cited.

57 The leading case is Home Tel. \& Tel. Co. v. Los Angeles, supra note 56.

58 Where specific action of a subordinate organ of the state is alleged to be contrary to the law of the state as expressed in its constitution or statutes and the action is subject to review by some other organ of the state, for example, by its supreme court, it is argued that unless and until the reviewing authority has sanctioned the action there is as yet 
But doubts about "unauthorized" official action do not concern us here. Here we are dealing with a rule of law made and enforced in a judgment by a state supreme court, "the ultimate voice of state law", ${ }^{59}$ authorized by the state constitution to determine conclusively the scope of its own authority. Its every judgment for purposes of review in the Supreme Court must be taken to be authorized state action.

Sedulously Mr. Justice Miller, delivering the opinion of the Court in the Civil Rights Cases, qualified his statement that "individual invasion of individual rights is not the subject matter of the amendment," by reiterating that the statement referred to private action that is exclusively such, unaided, unsanctioned and unsupported by action of any organ of state government.

He said that the Amendment applies to "the action of state officers, executive or judicial." ". ". . some state action through its officers or agents ...." "... the prohibitions of the amendment are against state laws and acts done under state authority." 62 "... or state action of some kind . ..." ". . such acts or proceedings as the state may commit or take." ${ }^{\prime 4}$

no state action. See the dissent of Mr. Justice Holmes in Raymond v. Chicago Traction Co. (1907) 207 U.S. 20, 40. Perhaps all that Mr. Justice Holmes meant, however, was that a regard for federalism required a working rule that the federal courts should not intervene until local remedies were exhausted. See ibid. at 41. I do not belicve that he had in mind the "stripping doctrine" of Ex parte Young (1908) 209 U.S. 123, 159-160 (see the note by Mr. Justice Brandeis in Iowa-Des Moines Bank v. Bennett (1931) 284 U.S. 239, 246), which fictionally regards the "illegal" or "unauthorized" action of officers as the action of individuals, although in fact they act in their official capacity. In cases of the kind in question, the body that has acted has had "jurisdiction" or authority to act given it by the state and it seems, therefore, that its action is state action whether it acts rightly or wrongly. See the recent discussion of this problem in Snowden v. Hughes (1944) 321 U.S. 1, which went off, however, on the ground that the action of the subordinate state body was not unconstitutional even if regarded as state action because its alleged discrimination was a rational one and therefore one the Equal Protection Clause does not forbid a state to make.

Moreover the doubt in that group of cases, whether there is state action, disappears when "the judicial power of the State has been exerted in justifying" the action. IowaDes Moines Bank v. Bennet (1931) 284 U.S. 239, 246.

59 Mr. Justice Frankfurter in Snowden v, Hughes (1943) 321 U.S. 1, 17.

60 Civil Rights Cases (1883) 109 U.S. at 11.

${ }^{61}$ Ibid. at 13.

62 Ibid.

63 Ibid.

64 Ibid. at 15 . 
"In this connection it is proper to state that civil rights, such as are guaranteed by the Constitution against State aggression, cannot be impaired by the wrongful acts of individuals, nnsupported by State authority in the shape of laws, cnstoms, or judicial or executive proceedings. The wrongful act of an individual, unsupported by any such authority, is simply a private wrong . ..."

The use here of the words "laws, customs, or judicial ... proceedings" shows clearly that a decree of a state court enforcing its customary or judge-1nade common law in aid of a forbidden discrimination is as much violation of the Fourteenth Amendment as is like enforceinent of a state statute which makes such a discrimination. It is prohibited state action.

While the Civil Rights Cases dealt with the power given Congress by Section 5 of the Fourteenth Amendment to enforce the Amendment, the decision necessitated a determination of the scope of the rights which Congress was authorized to protect or enforce. Reading the Amendinent literally, apart from the intention of Congress in proposing it, it was held not to lay down any rule of substantive law applicable to purely private conduct but to be only a limitation on state action,-stricting speaking, a grant of immunity to private persons from defined harmful action by any state. Congress, it was held, was authorized to adopt any measures reasonably adapted to protect these immunities from invasion by state action. The precise question was, did the Equal Protection Clause impose as a rule of substantive law that every private operator of an inn, public conveyance, theatre or other place of public amusement should serve every applicant without racial discrimination. If this was one of the commands of the Amendment, Congress could validly reiterate it, as did the Civil Rights Act of 1875, and further enact, as that Act did, that any private person who disobeyed the command should be subject to criminal prosecution or payment of a pecumiary penalty to the person aggrieved. In holding the Act not within the power granted Congress, the Court said: "It proceeds ex directo to declare that certain acts committed by individuals shall be deemed offences, and shall be prosecuted and punished by proceedings in the courts of the United States. It does not profess to be corrective of any constitutional wrong committed by the states; it does not make its operation to depend upon such wrong committed." 66

\footnotetext{
65 Ibid. at 17.
}

60 Ibid. at 14 . 
Where there is forbidden state action Congress has power to correct or annul it, said the Court, and alluded to one mode of correction Congress has adopted, by giving the Supreme Court appellate jurisdiction over a state court judgment that supports any forbidden state action, ${ }^{37}$ a mode of correction peculiarly appropriate where the state court itself has been the sole actor in rendering a judgment based upon its conception of the common law of the state.

What were the acts of mdividuals involved in the Civil Rights Cases? They were acts of a kind that accomplish their objective without any aid whatever from the state. If an innkeeper refuses entertainment to a Negro, or any other person, because of his race, that is the end of the matter. The refusal to serve operates of itself without any aid or intervention by the state or any of its officers or agents. The states, if they choose, may make such discriminations illegal, as many of them have by civil rights statutes, ${ }^{63}$ several of them broader in their coverage than the Congressional Act of 1875; but the Constitution, as interpreted in the Civil Rights Cases, does not permit Congress to do so, and allows the states to refrain from doing so. In any state that keeps hands off, these discriminatory business practices may go on unrestrained, a result that enduced the vigorous dissent of Mr. Justice Harlan. ${ }^{69}$ But while the state may intervene to prohibit such discriminatory practices it cannot intervene to aid and enforce them.

The refusal of a landowner to sell to an offerer because the latter is a Negro, like the refusal of an innkeeper to serve an applicant for the same reason, is action by a private person which accomplishes its objective without need for calling on the state for aid. It is immaterial that he refuses because he thinks a restrictive agreement he has made binds him. The refusal of the landowner is no more forbidden by the Constitution than that of the innkeeper. Thus it has been correctly said by one court that no man can be compelled to sell his land to a Negro, ${ }^{70}$ no doubt meaning compelled to accept an offer by a

67 Ibid. at 12 .

68 Cited and digested in MaNgum, The LEgar Status of the Negro (1940) c. III, 26-77.

69 Supra note 60 , at 26.

70 Corrigan v. Buckley (1924) 299 Fed. 899, 901, appeal dism. (1925) 271 U.S. 323: "The constitutional right of a negro to acquire, own, and occupy property does not carry" with it the constitutional power to compel sale and conveyance to him of any particular private property. The individual citizen, whether he be black or white, may refuse to 
Negro. That is not the issue. The question is whether a state can prevent purchase by a Negro from a willing seller, or prevent occupancy by a Negro who has bought from a willing seller. In every one of the reported cases of litigation over these racial restrictions an owner has contracted to sell or lease or has actually sold or leased to a member of an excluded race. Obviously he has done so willingly. The question is whether his agreement with third persons not to do so may be enforced by the state. There is nothing unjust in holding him to his bargain so far as he alone is concerned but the state is denied power to enforce it because enforcement would work a prohibited discrimination against the buyer because of his race.

The discriminatory agreements, conditions or covenants in deeds that exclude Negroes or other racial minorities from buying or occupying residential property so long as they remain purely private agreements are not unconstitutional. So long as they are voluntarily observed by the covenantors or the restricted grantees no action forbidden by the Constitution has occurred. But when the aid of the state is invoked to coinpel observance and the state acts to enforce observance, the state takes forbidden action. The deed to the colored buyer cannot be cancelled by purely private action. The Negro cannot be ousted from occupancy by purely private action. When a state court cancels the deed or ousts the occupant, the state through one of its organs is aiding, abetting, enforcing the discrimination.

Of course the constitutional issue turns on two questions. First, there must be state action making a forbidden discrimination. Second, the state action must forsooth be a forbidden one. I shall come to the second after further discussing the first. Although further discussion seems an elaboration of the obvious,- - the very obvious proposition stated by the Court in Twining v. New Jersey: ${ }^{71}$

"The judicial act of the highest court of the State, in authoritatively construing and enforcing its laws is the act of the State."72

This was said not in the common case of the state court construing and applying a statute but where it gave effect to a rule of procedure held by it to be a part of the common law of the state. In the upshot

sell or lease his property to any particular individual or class of individuals. The state alone possesses the power to compel a sale or taking of private property, and that only for public use."

i1 (1908) 211 U.S. 78.

72 Ibid. at 90-91. 
the Court held that the particular rule the state of New Jersey thus adopted was not one that she was forbidden by the Fourteenth Amendment to adopt. ${ }^{73}$ State supreme court judges are rarely lacking in a sense of propriety in procedure, but when the rare case occurs of a state court judgment founded upon a common law, or judgemade, rule of procedure that is not due process, the Supreme Court acts upon the principle announced in the Trining case and reverses that judgment as state action in violation of the Fourteenth Amendment.

So in Brinkerhoff-Faris Co. v. Hill ${ }^{\text {i4 }}$ the only unconstitutional wrong which the plaintiff asserted Missouri had inflicted upon it was demial by the Supreme Court of Missouri of the relief it sought. The United States Supreme Court said: "We are of opinion that the judgment of the Supreme Court of Missouri must be reversed, because it has denied to the plaintiff due process of law-using that term in its primary sense of an opportunity to be heard and defend its substantive right." 75 "If the result above stated were attained by an exercise of the state's legislative power, the transgression of the due process clause of the Fourteenth Amendment would be obvious. . . . The federal guaranty of due process extends to state action through its judicial as well as through its legislative, executive or administrative branch of government." "is

So in Powell v. Alabama ${ }^{\pi 7}$ the only wrong complained of was action by a state court, trying Powell without adequate appointment of counsel. The Supreme Court of the United States reversed the judgment of the Supreme Court of Alabama, which sustained the trial court, because the state of Alabama had taken action forbidden by the Fourteenth Ainendment. ${ }^{78}$

So where a state trial court proceeds with a trial to conviction under the domination of a mob hostile to the accused and no higher

73 Like cases are Howard v. Kentucky (1906) 200 U.S. 164 (common law rule about discharge of jurors); Garland v. Washington (1914) 232 U.S. 642 (common law trial procedure).

74 (1930) 281 U.S. 673.

T5 Ibid. at 678.

76 Ibid. at 679-680.

77 (1932) 287 U.S. 45.

78 Chief Justice Hughes later succinctly digested the case: "The State may not deny to the accused the aid of counsel. Powell v. Alabama, 287 U.S. 45." Brown v. Mississippl (1936) 297 U.S. 278, 286. 
court of the state supplies a corrective, the action of these courts is state action forbidden by the Fourteenth Amendment. ${ }^{79}$

There is equally state action where a state court founds a judgment upon a rule of substantive law which it "finds" in the common law, or judge-made law of the state. Since a rule so made and applied is produced by state action it is subject to the same test of its validity under the Fourteenth Amendment as it would be if made by that other form of state action, enactment by the state legislature.

So in Bridges v. California ${ }^{80}$ when a California court inflicted a contempt sentence under its version of the common law of the state with respect to punishable contempts of court, the Supreme Court of the United States set aside that sentence as state action infringing the command of the Fourteenth Amendment that no state shall deny freedom of speech.

In Cantwell v. Connecticut ${ }^{31}$ the petitioner had been convicted of the Connecticut common law offense of inciting a breach of the peace. $^{82}$ The state supreme court had affirmed the conviction. Undoubtedly therefore by the judge-made law of Connecticut the acts of Cantwell constituted a criminal offense. The Supreme Court of the United States had no power whatever to reinterpret or redefine the common law of Connecticut. But it did have power and exercised it to set aside the state court judgment on the ground that it infringed the freedom of speech guaranteed by the Fourteenth Amendment. It could do so only if the action of the Connecticut courts was state action within the prohibition of that Amendment.

Likewise when the courts of Illinois and of New York granted injunctions against picketers on the ground that their conduct was tortious by the common law of their states the Supreme Court reversed the judgments as state action violating the Fourteenth Amendment. ${ }^{83}$ A state cannot make, in any manner, and enforce, a rule of substantive law that abridges the freedom of speech which the Fourteenth Amendment commands all states to respect.

The doctrine of the four recent cases just discussed is not new. In 1897 the Court held that if by a judgment of the courts of a state,

79 Moore v. Dempsey (1923) 261 U.S. 86.

80 (1941) 314 U.S. 252.

81 (1940) 310 U.S. 296.

82 The fifth count. Ibid. at 300, 307-311.

83 A.F. of L. v. Swing (1941) 312 U.S. 321 , rev'g 372 Ill. 91, 22 N.E. (2d) 857 ; Bakery Drivers Local v. Wohl (1942) 315 U.S. 769, rev'g 284 N.Y. 788, 31 N.E. (2d) 765. 
no other organ of the state acting, private property was taken for public use without just compensation this would be state action reaching a result prohibited by the Fourteenth Amendment. ${ }^{81}$ It was in that case that for the first time the Due Process Clause was construed as a limitation on the content or substance of state laws, and a correct digest of the case is that the limitation applies to state laws made through exercise of the decisional powers of state courts as well as to laws enacted by a state legislature.

When we turn from the restriction imposed upon the states by the Due Process Clause of the Fourteenth Amendment to the restriction imposed by the companion clause,- that a state shall not deny equal protection of the laws, is any different interpretation permissible? If a given method of state action committing one evil is condemned can the same method be used by the state to accomplish the other evil with impunity? The absence of decisions of the Supreme Court squarely ${ }^{85}$ in point on the Equal Protection Clause is doubtless due to the rarity with which state courts have made common law rules of procedure or of substantive law that are so discriminatory as to constitute demal of equal protection.

Suppose, however, that a state court rules in the trial of a Negro for crime that by the common law of the state Negroes are ineligible to serve as jurors, and the supreme court of the state affirms that ruling. Is there any doubt that a judgment convicting a Negro as a result of a trial in which that rule of procedure is acted upon would be reversed by the Supreme Court as state action denying equal protection of the laws?

The Supreme Court has three times said, speaking once through Mr. Justice Gray, again through Mr. Justice Holmes and again through Mr. Chief Justice Hughes:

"Whenever by any action of a State, whether through its legislature, through its courts, or through its executive or administrative

84 Chicago, B. \& Q. R. Co. v. Chicago, 160 U.S. 226.

85 In Hysler v. Florida (1941) 315 U.S. 411, 422, the Court assumed that if a state supreme court refused to grant a form of relief to one suitor which it habitually granted to others in like circumstances its action would be state action violating the Equal Protection Clause of the Fourteenth Amendment. See also Howard v. Fleming (1903) 191 U.S. 126, 136, where the Court assumed that inequality of sentences imposed by a state court upon three jointly prosecuted criminals might be such as to justify setting the sentences aside, as denials of equal protection. And see Howard v. Kentucky (1906) 200 U.S. 164, 176. 
officers, all persons of the African race are excluded solely because of their race or color, from serving as grand jurors in the criminal prosecution of a person of the African race, the equal protection of the laws is denied to him contrary to the Fourteenth Amendment of the Constitution of the United States." 86

Likewise in the field of substantive law. If the supreme court of a state should affirm a judgment based upon the judge-made law of the state that Negroes, like aliens at common law, lack legal capacity to hold land would not the Supreme Court hold that the making and enforcement of that rule by the state courts was state action violating the Equal Protection Clause? That such a rule of law if made by state statute would be such a denial is obvious.

So we pass to the second phase of the constitutional issue. Where a state court renders a judgment based upon the common law of a state ousting a Negro from occupancy of a residence because (1) he is a Negro and (2) because there is an agreement between private persons that no Negro shall be allowed to occupy that residence, does this state action deny to the Negro the equal protection of the law?

The cases under the Due Process Clause above discussed establish incontrovertably that this is state action. Is it forbidden state action? The test should be as under the Due Process Clause whether a state statute embodying the same rule would be violative of the Equal Protection Clause. I say this not because either of these clauses of the Amendment singles out the legislature as an organ of the state that is restricted, but because the practice of holding statutes void that violate the clause is familiar.

I shall therefore hypothesize a state statute in its most favorable form. If the statute were so worded as to legalize restrictive agreements when they bar Negroes or non-Caucasions but not when they bar whites its violation of the Equal Protection Clause would be obvious. A few courts in enforcing restrictive agreements against Negroes have assumed themselves beyond reproach by asserting that they would equally enforce restrictive agreements against sale to or occupancy by whites.

To fit the statute to this asserted scope of the judge-made law our hypothetical statute should declare legal and enforceable any private agreement of the kind here in question regardless of the race

86 Carter v. Texas (1900) 177 U.S. 442, 447; Rogers v. Alabama (1904) 192 U.S. 226, 231; Norris v. Alabama (1935) 294 U.S. 587.589 (italics added). 
or races the parties to it see fit to exclude from purchase or occupancy. Let us examine a statute which has this appearance of even-handed justice. What would it authorize? It would authorize a sort of local option, whereby the owners of property in any block or district could establish it as exclusively a white block or district or as an exclusively Negro block or district, whichever they chose. Instead of a statute or ordinance which itself determines what areas should be exclusively white and what exclusively Negro, as did the Louisville ordinance held invalid in Buchanan v. Warley, ${ }^{87}$ the supposed statute would leave the picking out of the areas to the option of property owners. In this respect it more nearly resembles the New Orleans ordinance held invalid in Harmon v. Tyler, ${ }^{88}$ which barred whites or Negroes froin any "community or portion of the city ... except on the written consent of a majority of the persons of the opposite race inhabiting such community or portion of the city." 80

That the judge-inade rule we are examining and the hypothetical statute imitating it could be used to produce the same result as these ordimances was conceded in the earliest state decision in which the constitutional issue was discussed. The Missouri Supreme Court recognized that the rule it was declaring would legalize racial residential segregation, but defended it as racial separation, similar to the separation of the races on passenger carriers ${ }^{00}$ which the Supreme Court had held in Plessy v. Ferguson ${ }^{91}$ might be required by state statute. Indeed the Missouri court said, "The discrimination against negroes has been recognized by the courts in other matters where their presence has been objected to for reasons similar to the reasons advanced here." 92 Other courts have also referred to decisions sustaining state separate coach and state separate school laws as justifying their judge-made rule for residential racial separation..$^{33}$

87 Supra note 18.

88 (1927) 273 U.S. 668.

${ }^{89}$ Quoted in Tyler v. Harmon (1925) 158 La. 439, 104 So. 200.

90 Koehler v. Rowland, supra note 14, at 585, 205 S.W. at 220.

91 (1896) 163 U.S. 537.

92 Koehler v. Rowland, supra note 14, at 585.

93 Meade v. Dennistone (1938) 173 Md. 295, 300-301, 196 A. 330, 332 ; Corrigan v. Buckley, supra note 125 at 901-902; Parnalee v. Morris (1922) 218 Mich. 625, 627, 188 N.W. 330. 
The soundness of the decisions relied upon need not be doubted here, though it has been questioned by Chief Justice Taft. ${ }^{94}$ It is sufficient to distinguish them. Separate coach laws are not sustained by the Supreme Court merely because they forbid the white to ride in the Negro car as well as forbid the Negro to ride in the white car. The sine qua non of their validity is that they require the coaches to be equal. Without this equality the Court would hold that the statute makes a forbidden racial discrimination. The statutes may be more honored in the breach than the observance but equality is the consti-

94 "The question here is whether a Chinese citizen of the United States is denied equal protection of the laws when he is classed among the colored races and furnished facilities for education equal to that offered to all, whether white, brown, yellow or black. Were this a new question, it would call for very full argument and consideration ... " Taft, C. J. for the Court in Gong Lum v. Rice (1927) 275 U.S. 78, 85-86.

Plessy v. Ferguson, supra note 91, the first decision of the Supreme Court sustaining a state statute which required separation of races in public carriage of passengers, came to the Court when Reconstruction was being reconstrued. If that decision were now reconsidered several fallacies would be discovered in the opinion. It relied in part upon Roberts v. City of Boston (1849) 5 Cush. 198; decided before the adoption of the Fourteenth Amendment. It relied, at pp. 545, 550-551, upon the assumed constitutionality of an Act of Congress requiring separation in the schools of the District of Columbia, where the Equal Protection Clause has no application. The Court said that the Constitution required "the absolute equality of the two races before the law" but not "social equality" (p. 544) and assumed that the Negro's demand for indiscriminate accommodation on public carriers was a demand for the latter rather than one for non-discriminatory treatment in business relations. Although the Court referred to the white race as the "dominant race" (p. 549) it gave no weight to the fact that the law in question was enacted by a white legislature. Indeed it made fanciful allusion to the possibility that Negroes might become dominant in a legislature and enact an identical law (p. 551). When a dominant race, whether white or Negro, demands separation it is fallacious to say, as the Court did, that the intention and effect is not to impose a "badge of inferiority" on the other. When a Negro workingman or woman is seated in the third seat of a streetcar on St. Charles Avenue in New Orleans and a white man or woman is seated in the fourth seat, separated only by a bit of wire mesh ten inches high, set on the back of the third seat, there is a "separation" that is merely a symbolic assertion of social superiority, a "ceremonial" separation.

The Court said, "If one race be inferior to the other socially, the Constitution of the United States cannot put them upon the same plane" (p. 552). That was a good reason for interpreting the equality requirement of the Fourteenth Amendment as not touching discrimination in private social relations, but no reason at all for holding that a state by its laws could command that this social discrimination should be carried over into the field of public business relations, and even into its public institutions. The Court's assumption that "absolute equality of the two races before the law" would be achieved if separation in public carriers and in public schools was qualified by the requirement of "equal facilities" has proved to be a fallacy, because the latter requirement has proved to be too difficult of enforcement. Should the Constitution be construed as intending a kind of equality in civil rights that is unenforceable? 
tutional ground upon which they stand. Moreover, equality of the cars in every respect is in fact a possibility. All that is necessary to bring about equality in fact is rigid law enforcement. Residential separation cannot stand that test. No two residential districts are equal. Even in mass production though two houses may be identical their locations are different. In the specific performance of contracts to convey land courts have traditionally held that every bit of land is unique. In doing so they have recognized as fact what is fact. Obviously therefore when a Black is barred from buying or residing on Whiteacre no equality results to him from the fact that there is other property he may buy or live in, nor would equality be produced by reason that White is or may be barred from buying or living on Blackacre. The discriminatory inequality is even more evident when it is perceived that the practical working of such "even handed" justice would be that Negroes would be barred from the best residential districts and whites could be barred from the predominantly colored districts which by the sad actual facts are not so good, to state it mildly. Always theoretically assuming that Negroes would enter into restrictive agreements barring whites. Surely such a state of the law will not "be sicklied oe'r with a pale cast" of theoretical equality, by imagiring a neighborhood of Negro millionaires bent upon preventing any white family from intruding among them.

What Mr. Justice Cardozo said of another equalitarian provision of the Constitution is applicable here. "We are not to whittle it down by refinement of exception or by implication of a reciprocal advantage that is merely trivial or specious." cupancy of the house of his choice is it not specious to say that there may be houses elsewhere that he may occupy from which whites may be excluded by restrictive agreements?

The hypothetical statute is impartial only in that it permits the same discrimination against a member of one race that it permits against a member of any other race. The contention that thereby it satisfies the Equal Protection Clause put baldly is that so long as a state helps Negroes to bar whites from their neighborhood it may help whites to bar Negroes from their neighborhood. ${ }^{96}$ But in every case

95 Smith v. Loughman (1927) 245 N.Y. 486, 496.

96 This contention is made in two notes, apparently by the same writer, in (1916) L.R.A. 1916B 1208, and (1920) 9 A.I.R. 120, followed with approval in Title Guarantce \& Trust Co. v. Garrott (1919) 42 Cal. App. 152, 155, 183 Pac. 470, 471. 
of state court enforcement of a restrictive agreement the blow falls upon an individual, not upon a group as such. The command of the Clause is that no state shall deny to any person the equal protection of the laws. The immunity granted is an individual one. When because of an agreement of one group a state ousts a Negro from residing in the home of his choice it does not square itself with the conmand of the clause by enforcing the agreement of another group by which a white man is barred from the home of his choice. Instead of complying with the Clause, the state commits two violations of it. Two individuals, one Negro and one white, has each been discriminated against because of his race. Under the Equal Protection Clause, as under Due Process Clauses, the Supreme Court has several times pointed out that "the essence of the constitutional right is that it is a personal one. ... It is the individual who is entitled to the equal protection of the laws." 97

RACIAI RESIDENTIAL RESTRICTIONS DISTINGUISHED FROM RESTRICTIONS AGAINST OTHER USES

Restrictions against many kinds of uses of property may validly be imposed by neighborhood agreements or by conditions or covenants in deeds. In 1879, for example, the Supreme Court of the United States held that by the judge-made land law of the Territory of Colorado a condition in a deed conveying a fee simple, that intoxicating liquor should never be manufactured or sold on the premises was a legal restraint on alienation and enforceable. ${ }^{98}$

In its opinion the Court said:

"The reports are full of cases where conditions imposing restrictions upon the uses to which property conveyed in fee may be subjected have been upheld. In this way slaughter-houses, soap-factories, distilleries, livery-stables, tanneries, and machine-shops have, in a multitude of instances, been excluded from particular localities, which, thus freed from unpleasant sights, noxious vapors, or disturbing noises, have become desirable as places for residences of families. To hold that conditions for their exclusion from premises conveyed are inoperative, would defeat numerous arrangements in our large cities for the liealth and comfort of whole neighborhoods." 99

97 McCabe v. Atchison, T.\& S. F. R. Co. (1914) 235 U.S. 141, 161-162; Missouri ex rel. Gaines v. Canada (1938) 305 U.S. 337, 351. See also Mitchell v. United States (1941) 313 U.S. 80, 97.

98 Cowell v. Springs Co. (1879) 100 U.S. 55.

99 Ibid. at 57 . 
Several courts have relied upon the legality of restrictions against such uses in holding that restraints against use by any member of a race of people are equally legal. These courts have done so, not in considering the constitutionality of enforcing the latter kind of restriction, but in making up their minds about the land-law of their jurisdiction. That there is a constitutional distinction seems not to have occurred to them. The constitutional distinction is obvious. All the uses of the kind listed in the Supreme Court opinion above quoted and many others may be barred from residential districts by state legislation, and therefore may be barred by other forms of state action including judgments of its courts enforcing private agreements. State zoming laws may validly exclude such uses from residential districts. ${ }^{100}$ So long as it is unconstitutional for a state to require racial segregation by zoning statutes, however, it is equally unconstitutional for the state to bring it about by any other form of state action. The familiar test of whether state action runs afoul of the Equal Protection Clause is whether a discrimination it makes has a rational objective. If it is consistent with democracy and the equality before the law which the Equal Protection Clause commands the states not to deny, the state may segregate its residents racially, by one form of action as well as another. Otherwise not.

BUCHANAN V. WARLEX ${ }^{101}$

In this case the Supreme Court held a state law unconstitutional, specifically a city ordinance which forbade any white person or any Negro person to move into and occupy as a residence any house in a city block in which a majority of the houses were already occupied by persons of the other race or color. The attack upon the ordinance was inade by a white man who had contracted to sell to a Negro a lot in a block in which a majority of the houses was then occupied by whites, the Negro's pronise to buy being conditional, by the terms

${ }^{100} \mathrm{~A}$ statute prescribing different maximum heights of buildings in different sections of a city does not deny equal protection. Welch v. Swasey (1909) 214 U.S. 91. Nor an ordinance excluding livery stables from specified areas in a city. Reinman v. Little Rock (1915) 237 U.S. 171. Nor one forbidding emission of dense smoke in specified portions of a city. Northwestern Laundry v. Des Moines (1916) 239 U.S. 486. Nor one excluding the manufacture of brick from residential areas. Hadacheck v. Los Angeles (1915) 239 U.S. 394. Nor a comprehensive zoning ordinance of the usual type, creating residential business and industrial districts. Euclid v. Ambler Co. (1926) 272 U.S. 365, 388.

101 Sapra note 18. 
of the contract, upon his having a legal right to reside thereon. The white seller sought specific performance and challenged the validity of the ordinance. That the issue was raised by the white seller led the Court to consider it from his point of view, but not exclusively so, as will be seen. The specific ground of decision was that the ordinance in curtailing the owner's jus disponendi deprived him of a property right without due process of law. The decision was made in the heyday of resort to the Due Process Clause of the Fourteenth Amendment to annul state laws that in the judgment of the Court "unreasonably, arbitrarily or capriciously" interfered with private economic relations. The ordinance made no racial discrimination among sellers of property. Whether the seller of a house in a white block was white or colored there was the same restraint upon his alienation to a Negro buyer, the restraint being that either a white seller or a Negro seller was less likely to obtam a Negro buyer of a house in which the buyer could not legally reside. Vice versa, whether the owner of a house in a Negro block was white or colored the ordinance equally reduced his possibility of finding a white buyer. Looked at exclusively from the standpoint of its effect upon sellers the ordinance could not be said to violate the Equal Protection Clause.

When, however, the ordinance is considered in its effect upon buyers it is clearly a racial discrimination. Not by saying that a Negro could not buy a house in a white block but by saying that though he legally acquired the house he could not live in it, although if a white acquired the house he could live in it. This issue would have been the focal one had the validity of the ordinance been challenged by the buyer. Raised as the issue was it was sufficient for the court to dispose of it by its then standard of interpretation of the Due Process Clause.

The only other decision of the Supreme Court on the validity of such ordinances has been in the case of Harmon v. Tyler. ${ }^{102}$ A decision of the Supreme Court of Louisiana holding such an ordinance valid was reversed in a brief inemorandum opinion "on the authority of Buchanan v. Warley". In the Louisiana case the issue was raised, as in Buchanan v. Warley, in a manner that brought to the fore the right of an owner to dispose of his property, specifically, to lease a house in a white block to a Negro as tenant. The suit was one to enjoin him from doing so. Thus the Court could rely upon its former

102 Supra note 88. 
decision that such curtailment of the jus disponendi violated the Due Process Clause.

Technically, therefore, neither case decides that a state statute which forbids a man to reside in a particular residence solely because of his race is a violation of the Equal Protection Clause. The Court, however, in Buchanan v. Warley did not close its eyes to this issue. It quoted from a former opinion statements that a state may not make the enjoyment of any civil right dependent upon race or color, that "all persons, whether colored or white, shall stand equal before the laws of the states." 103

It is well known that the doubts expressed in Congress whether the statute called the Civil Rights Bill of $1866^{104}$ was authorized by the Thirteenth Amendment led Congress to incorporate in the Fourteenth provisions that would settle those doubts. With this in mind the Court said,

"The statute of 1866, originally passed under sanction of the Thirteenth Amendment, 14 Stat. 27, and practically reenacted after the adoption of the Fourteenth Amendment, 16 Stat. 144, expressly provided that all citizens of the United States in any State shall have the same right to purchase property as is enjoyed by white citizens. Colored persons are citizens of the United States and have the right to purchase property and enjoy and use the same without laws discriminating against them solely on account of color. Hall v. DeCuir, 95 U.S. 485, 508. These enactments did not deal with the social rights of men, but with those fundamental rights in property which it was intended to secure upon the same terms to citizens of every race and color. Civil Rights Cases, 109 U. S. 3, 22. The Fourteenth Amendment and these statutes enacted in furtherance of its purpose operate to qualify and entitle a colored man to acquire property without state legislation discriminating against. him solely because of color."105

These statements show clearly that the Court's conception of the Equal Protection Clause was that its requirement is not satisfied by a statute which makes a false pretense at equality by excluding whites from black blocks as an offset to exclusion of blacks from white

103 Ibid. at 77, quoting from Strander v. West Virginia (1879) 100 U.S. 303, 307.

104"All citizens of the United States shall have the same right in every State and Territory, as is enjoyed by white citizens thereof to inherit, purchase, lease, sell, hold and convey real and personal property." 14 Stat. $27, \$ 1$.

105245 U.S. $60,78-79$. 
blocks. The incidence of the law upon the individual affected in each instance of its application is determinative. Denial to one man because of his race or color the privilege of purchasing and residing in one house is not made equal by denying to some other man of a different race or color the privilege of living in another house. The Court quoted, "the essence of the constitutional right is that it is a personal one." 106 There are other significant passages in the opinion.

"That there exists a serious and difficult problem arising from a feeling of race hostility which the law is powerless to control, and to wlich it must give a measure of consideration, may be freely admitted. But its solution cannot be promoted by depriving citizens of their constitutional rights and privileges. ...

"It is urged that this proposed segregation will promote the public peace by preventing race conflicts. Desirable as this is, and important as is the preservation of the public peace, this aim cannot be accomplished by laws or ordinances which deny rights created or protected by tle Federal Constitution." 10\%

The supposed effect of such ordinances to protect property values was said not to justify them.

"It is said that such acquisitions by colored persons depreciate property owned in the neighborhood by white persons. But property may be acquired by undesirable white neighbors or put to disagreeable though lawful uses with like results."108

Thus the Court no doubt saw that "the ordinance while equal and reciprocal in phraseology, as regards the two races, does in reality, the facts of life being what they are, discriminate heavily against the negro race ...."109

The Court was not deaf to the argument of counsel that the ordinance's "predominant purpose was to place the negro, however industrious, thrifty and well-educated, in as inferior position as possible with respect to his right of residence, ..." ${ }^{\prime 10}$ and that inequality to the Negro "is not removed by forbidding white owners to live on their own land in other parts of the city, for the Constitution cannot be satisfied by any such offsetting of inequalities." 111

${ }^{106}$ Ibid. at 80 . See supra note 97.

$10 \pi$ Ibid. at 80-81.

$108 \mathrm{Ibid.}$ at 82.

$109 \mathrm{My}$ quotation from note in (1918) 31 HARv. L. Rev. 475, 479.

110 Supra note 18 , at 62.

111 Ibid. at 63. 


\section{CORRIGAN V. BUCKLEY ${ }^{119}$}

In a series of cases, ${ }^{113}$ beginning in 1924, the Uinted States Court of Appeals for the District of Columbia has established, until and unless the Supreme Court overrules, that by the land-law of the District a restriction against sale to any meinber of a specified race is a lawful restraint on alienation. In the first of these cases, Corrigan v. Buckley, an appeal to the Supreme Sourt was dismissed for want of jurisdiction. Applications for certiorari have been denied by the Supreme Court in others of these cases. ${ }^{114}$ So far that Court has declined to speak the final word on the land-law of the District. It is probable that the next application for review on certiorari will be granted. Mr. Justice Rutledge when sitting in the Court of Appeals concurred in a decision in which enforceinent was denied because of change in the character of the neighborhood, qualifying his concurrence by adding, "if such a covenant as is involved in this case is valid in any circumstances, as to which I express no opinion, ..." ${ }^{115}$ In another recent decision of the Court of Appeals there has been a forcefully argued dissent. ${ }^{116}$

As previously stated ${ }^{117}$ the opinion of the Supreme Court in dismissing the appeal in Corrigan v. Buckley has been frequently relied upon by state courts as settling the constitutionality of court enforcement of race residential restrictions. So far as state court enforcement is concerned, that issue could not possibly be raised in a case turning upon the law of the District of Columbia. The restriction upon the states made by the Equal Protection Clause has no application to the governinental organs of the District.

While the Fifth Amendinent's Due Process Clause is applicable to the courts of the District, imposing the same restriction upon them as the Due Process Clause of the Fourteenth inposes on the states, and their courts, Mr. Justice Sanford, for the Court, stated definitely that the issue whether the district court's enforcemnt of the covenant violated the Due Process Clause of the Fifth Ainendment was not properly raised and was not before the Court. One defendant had pleaded that the "indenture or covenant" was "void in that the same

112 Supra note 25.

113 Ibid.

114 Ibid.

115 Hundley v. Gorewitz, supra note 25, at 25.

116 By Associate Justice Edgerton, Mays v. Burgess, supra note 25.

117 Supra p. 6. 
is contrary to and in violation of the Constitution of the United States." 118 The other defendant made the same plea relying upon the Fifth, Thirteenth and Fourteenth Amendments. ${ }^{119}$

While the Thirteenth is applicable in the District, the Court said the contention that it forbade such covenants was frivolous because that Amendment while "denouncing slavery and involuntary servitude, that is, a condition of enforced compulsory service of one to another, does not in other matters protect the individual rights of persons of the negro race." 120

The issue raised under the Fourteenth was likewise frivolous because that Amendment has no application to the District. It was in this connection that Mr. Justice Sanford said that that Amendment has no reference to any action of private individuals. Since his mind was focussed on the plea that the covenant was of itself unconstitutional, strictly read there is not even a dictum here, as state courts seem to have assumed, that state court enforcement of such restrictions would not be state action violating the Amendment.

The question to which the whole opinion is addressed is whether an issue had been raised that brought the case within the appellate jurisdiction of the Supreme Court by way of appeal. Nothing but a substantial issue arising under an act of Congress or the Constitution would suffice. The Court found no applicable act of Congress. Having found the issues raised under the Thirteenth and Fourteenth Amendments frivolous, the Court turned to the plea that the Fifth Amendment made the covenant void. This likewise was frivolous for the Fifth imposes its limitation on the organs of the national government and it had not been pleaded that the District court's enforcement of the covenant was a wrong complained of. On this poimt Mr. Justice Sanford is clear:

"And, while it was further urged in this Court that the decrees of the courts below in themselves deprived the defendants of their liberty and property without due process of law, in violation of the Fifth and Fourteenth Amendments, this contention likewise cannot serve as a jurisdictional basis for the appeal. Assuming that such a contention, if of a substantial character, might have constituted ground for an appeal under paragraph 3 of the Code provision, it was not raised by the petition for the appeal or by any assignment of

118 Supra note 25,271 U.S. at 328.

119 Ibid.

120 Ibid. at 330. 
error, either in the Court of Appeals or in this Court; and it likewise is lacking in substance." 121

The clause at the end of the quoted passage is obviously a dictum on a point which the Court stated was not before it.

What constitutional issue was decided by the Supreme Court in Corrigan v. Buckley? The case decides squarely that racial residential restrictions do not create slavery or involuntary servitude in violation of the Thirteenth Amendment, though the Court regarded this so clear on its past decisions as to have become a frivolous issue. Beyond this, nothing. Nothing but a very off-hand dictum that court enforcement of such restrictions in the District of Columbia would not violate the Due Process Clause of the Fifth Amendment. If the Court should ever so hold it would follow logically that state court enforcement of such restrictions is not forbidden by the Due Process Clause of the Fourteenth. In so deciding the Court would have to hold that the right to buy a home or to live in a home one has bought has not attained the dignity of a civil right like freedom of speech, of press, of religious worship, of assembly, embraced within the liberties secured by Due Process Clauses. Even those constructionists that rebel at reading into Due Process Clauses restraints on legislation regulating economic relations may find that governmental action dictating where a man shall make his home raises very different issues.

I shall not argue that question. It is sufficient to point out that even that question was not decided in Corrigan v. Buckley. More importantly it is obvious that the case did not decide anything with respect to the effect of the Equal Protection Clause as a limitation on the states.

The mere land-law question, whether such restraints are legal, the Supreme Court did not touch at all. When it comes to consider that question it may conclude that the courts of the District have misconceived the public policy of the United States in the seat of the nation's capital.

\section{CONCLUSION}

It is very true that a decision by the Supreme Court that court enforcement of these racial restrictions is unconstitutional, if it should so decide, will not solve the pressing need for decent housing for the great majority of Negroes and other large minority groups like those 
of Mexican descent. Their low economic status, their poverty, to use a plain word, compels them to reside in "districts where public services of water provision, sewage and garbage removal, street cleaning, street lighting, street paving, police protection and everything else is neglected or withheld while vice is often allowed. All this must keep the Negro masses inferior and provide reasons for further discrimination in politics, justice and bread-winning." 122 When the pressure of their numbers forces expansion beyond these districts, neighborhoods which have already deteriorated because industry, crime or vice have moved in are sometimes the only available ones. The result is a socially costly retardation in the cultural and social development of great masses of Americans. The condition of these masses is a concern of governments, national and state, for relief much more comprehensive than the annulment of racial residential restrictions. Even as to these masses, however, restrictive agreements often bar their expansion and force them to reside in congested areas, tending "to drive down their housing standard even below what otherwise would be economically possible."123

Racial residential restrictions also draw a color line through the higher economic levels. The Negro professional classes and the successful Negro business men who get on in the world by the practice of virtues which everyone lauds in others, are denied the privilege of the better residential environment that their economic status makes them able to attain.

"The fact is neglected by the whites that there exists a Negro upper and middle class who are searching for decent homes and who, if they were not shunned by the whites, would contribute to property values in a neighborhood rather than cause them to deteriorate." 124

The facts of a Michigan case ${ }^{25}$ illustrate the working of residential restrictions at the higher economic levels. It is the story of the rise in the world of Mr. and Mrs. William A. Starks. Mr. Starks was a parlor car conductor on the Pere Marquette. The Supreme Court of Michigan said, "They own a home on Beniteau Street, where they have lived eight years, and they own other property which they rent."

12. MyrdaL, AN AMTERICAN DIlediaca (1944) 643.

123 Ibid. at 625 .

124 Ibid.

125 Shulte v. Starks (1927) 238 Mich. 373, 213 N.W. 102. 
They bought a lot in the Oneida Park subdivision. "They paid $\$ 3,800$ cash for it and took title to it. They erected a house on it at a cost of $\$ 14,000$ which was also paid for in cash," said the court, and added, "Defendants appear to be thrifty." But adverse facts were disclosed. "The district is a high-class residential district ...," and the defendants are colored persons "by their own admissions", though "Mrs. Starks is quite light colored, and she testified that many times she had been taken for a white woman." The degree of whiteness of Mr. Starks did not appear. An association of residents in the district had made an agreement among themselves that none of the properties should "be sold, rented or leased to any person or class of persons whose ownership or occupancy would be injurious to the locality."128 Notwithstanding this agreement one of the parties had sold to the Starks.

By the law of Michigan, following California ${ }^{127}$ in this respect, the restriction against sale or lease was illegal, with the result that the Starks acquired a legal title to their new home. But could they live in it? In fact they were living in it. The discriminatory purposes of the parties to the private agreement had been defeated because one had broken faith with the others. By their own private action none of them could do anything about it. One of them appealed to the state and the state acting through one of its courts ordered $\mathrm{Mr}$. and Mrs. Starks to get out of their home. Had they been white no such order would have been made. Behind this order was all the power of the state to punish them for disobeymg it. If this action of the state against the Starks because of their color was not a violation of the Equal Protection Clause the purposes of that provision must be very narrow indeed. It has become the fashion to speak of the Reconstruction Amendments as sponsored by a wing of the Republican party opprobriously called the Radical Republicans, but it will be remembered that the Amendments passed Congress with a two-thirds vote in both Houses and were ratified by the legislature of three-fourths of the States. Although many Americans then had strong racial prejudices in their private social relations, as many still have, they deter-

128 While courts commonly say that restraints on alienation will be strictly construed the Michigan court construed this restriction against sale or lease to be also a restriction against use or occupancy by one of the proscribed class. It also construed the vague discription of the class to include Negroes, relying upon evidence that the parties to the agreement had consistently so construed it.

127 Supra p. 8. 
mined that in the sphere of state governmental action there should be no racial discrimination, and in particular no such discrimination against Negro citizens. The thoroughness of their program is evidenced by the fact that not only did the Fourteenth Amendment confer full citizenship upon Negroes born in the United States but substantially the same Congress that proposed that Amendinent modified the naturalization law to grant to alien Negroes residing in the United States the privilege of naturalization on an equality with white aliens. ${ }^{128}$ There are undoubtedly many Americans who would endorse a reactionary movement. That the courts of a dozen states have enforced racial residential restrictions is not the only evidence of that. But until reaction gains enough adherents to amend the Constitution by one of the authorized processes the regime of racial equality in legal rights and.state governmental action remains the "supreme Law of the Land."

129 Act of July 14, 1870, 16 Stat. 256. 